\title{
EXCLUSION AND PUBLIC POLICIES: Theoretical Dilemmas and Political Alternatives"
}

\section{Alba Zaluar}

It has become common currency in Brazil to speak of social exclusion when approaching a series of themes and problems not always clearly differentiated or rigorously defined. Widely employed in France, the concept proposes a new way for dealing with some of the questions related to the subject of underclass, without its theoretical purposes and consequences, inspired by and commonly used in the United States. The underclass concept, recently developed in discussions about dual or global cities (Sassen, 1991; Castels and Mollenkopf, 1992), uses class as its main reference, inasmuch as, in confrontation with the working class, it reflects what is lacking among the poor who do not have regular jobs, live in ghettos, belong to dysfunctional families, are addicted to illicit drugs and live in a neighborhood with high rates of criminality. The concept, thus, bears important theoretical resemblance to those theories developed in Latin America about the informal market and criminality, chiefly linking the social to

* Published originally in Revista Brasileira de Ciências Sociais, volume 12, n. 35, October 1997, pp. 29-48.

Translated by Maria Cristina de Andrade Vieira and revised by the author. the economic aspects. Exclusion, on the other hand, connects the economic to the political and social aspects. Nevertheless, besides citizenship and insertion in the national society, its references are the borders between groups and a non-explicit classificatory logic, not always clear to those who misuse the concept.

In order to clarify the mistakes and doubts assaulting those who wish to employ the concept of exclusion with accuracy, we must differentiate two sorts of problems: the theoretical and the practical/political, which have been often misconstrued by rhetoric.

\section{The theoretical problems}

The concept of exclusion comes, in fact, from a tradition in the study of symbolic systems that has prevailed in social thought, especially the one which was more influenced by Structural Anthropology. In this discipline, as it is well known, the analysis does not favor the policy of meanings in the discourse nor the relation of the discourse with its references, but instead the attributes in the chain of significants. In other words, the links between the name and the reality it covers, the signifier and 
the signified, do not matter as much as the connections between names within the system they form. This chain of significants is logically mounted upon inclusion/exclusion, in categories that intersects reality and allow communication. It is the classifying logic or binary logic (the yes/no of computers or of artificial intelligence) which is thus used to set differences, made possible by the signs they carry - the diacritic signs - resulting in a group of sounds or letters defined as significants. This logic corresponds to what the French call structurelle, that is, the formal relations between the elements of a symbolic system, to differentiate from structurale, which is associated to the social, to the moral, and to relationships between people, which also form a system. This anthropologic theory has proven to be a good one for thinking the idea of contrasting identities at the borders between groups that touch or confront one another and are symbolically represented as different. But the same theory presents problems when it is applied to all sorts of communities, more or less comprehensive, in which social or moral links, reciprocity, solidarity, mutuality, authority, and not only classificatory logic or the excluding game of power and discrimination, become a part of the complex scenario in which manifold actors command the social and political fields.

From the point of view of the symbolic system theory, we can assert that every classificatory system, or every community, insofar as they have their own peculiaridentities, will create exclusion: different religious, ethnic, racial, family or tribal groups, differentlocalities, nations, etc. These groups, however, will create exclusion by different procedures and different criteria, being more or less flexible, its borders being more or less defined, the links between its members being of a very different nature. This is the first difficulty in focusing just the yes/no of inclusion/exclusion. Any classificatory system that is based solely on terms of binary logic, inasmuch as it needs a clear boundary separating the parts - and this cannotbe reduced to polarized systems between only two categories - will produce exclusion, which is, therefore, a classifying trait upon which the structural concept of social identity is based. Even the systems of multiple categories, if their boundaries are strictly defined will create exclusion and potential conflicts. It is important, therefore, to understand the shady areas between communities or social groups, the processes of integration or rejection of each one, the intrinsic relationships between those included, as well as the relationships between the community or the group of included people with other groups that are of the same or of a different nature.

Some of these communities are more fluid, more open or more comprehensive than others. Some refer to the rights and obligations acquired by birth in the territory whereas some refer to bonds of kinship or of ancestry; others yet refer to the moral, intellectual or psychological characteristics of its members that are denied to the excluded. Nations can be born out of different combinations of these criteria, stressing one or the other, like for instance ancestry and race, as discussed in Tambiah's (1997) concept of ethno-nationalism, which will create a more or less excluding nation in so far as the acceptance of foreigners and immigrants is concerned. Some communities may be more indulgent in the processes of admission, conversion or inclusion whereas others may impose more demanding criteria. Most European countries owe most of their problems of exclusion to the nonacceptance of recent immigrants as members of society, creating a new form of cultural racism. In any event, to opt for inclusion is to opt for a common plateau of identity and of social belonging, overcoming differences.

In this sense, Brazil is one of the most accepting and less excluding nations of the world. The lack of ethnical and racial homogeneity makes it a multicultural country by vocation - in spite of the occurrence of "subtle" discriminations - and more open to the variety of the existing ethnical identities in the world. At the same time, its defense of hybridism softens the differences and, as a result of the mixture, creates a common racial and cultural nucleus. That is also why the violently excluding forms of biological racism of the past or cultural racism of the present are not remarkable in this country. In fact, Brazil is a country that theoretically rejects racism, even if in practice it presents signs of discrimination of blacks and mulattos stemming 
from the mixture between the blacks and "whites" who landed in Brazil and the Indians who were already here. The same, however, cannot be said of exclusions derived from poverty. It is when racial discrimination is combined with discrimination against the poor that we find distinct situations of exclusion in various areas, through different processes.

The other theoretical problem of this approach is that the existence of more or less closed communities or groups does not necessarily create a situation of injustice. To belong or not to belong to a family, a religious group, a particular ethnic group or a tribe doesn't necessarily mean to live a situation of social injustice, of privation or wanting in relation to other groups. When, then, does exclusion and injustice overlap? In this case, would the excluded and members of the underclass be the same? Despite the converging points and the juxtaposition, the debate on exclusion focus injustice from a point of view different from the one that sees it through the underclass concept.

French theoreticians who deal with today's social issues agree that, in order to think social injustice, one does not have to consider only the small groups anymore, but instead the national societies in their relations with national states. Exclusion as a manifestation of injustice (distributive) is manifest when people are systematically precluded from services, benefits and guarantees generally thought of as a right of the citizen, offered or assured by the state. Some point out that even then we would have greatly differentiated situations, levels and degrees of exclusion. It is therefore necessary to understand the processes that lead to exclusion and the particular content of different exclusions in order to reach a truer and less rhetoric understanding of exclusion. For instance, the life history and situations lived by street boys, young drug addicts, slum dwellers, unemployed workers, homosexuals, umbanda practitioners, blacks and mulattos are very different. Finally, others discuss justice as a more comprehensive concept, which encompasses not only the relations between society and state but also interpersonal relations, several commitments and possible participation of and between different sectors of soci- ety within public space which are not to be mistaken with the state or with the market. Which brings us to a new order of problems.

\section{The practical/political problems}

In its political dimension, the term exclusion - from the debate on the welfare state crisis currently refers to the exclusion or integration in the national society. That is how the term is used by most authors. Pierre Rosanvallon (1995), for instance, is a universalistic rather than a communitarian $^{1}$ in his perspective of exclusion, defining individual citizenship by the dimension of its political and civil participation in the national society. He thinks about the real rights, not about tho se written in declarations of men's universal rights, in national constitutions or other law codes that manifest their purely formal and unreal character since they are not always implemented. From this perspective, political and civil participation implies concrete responsibilities and duties, not simply those vaguely described in decrees. Thus a person is not simply a subject of rights assured by law, but rather a receiver of care and protection and, at the same time, someone who remains available to fulfill roles expected by society, that is, one should return the services received from the state. It is in this sense that he writes about "rebuilding the nation" with new solidarities, new social usefulness and new identities. In this manner, Rosanvallon combines the so-called social or collective rights, extending them to a category of people that are not taken into account, with individual rights and duties. It is not anymore a matter of the collective right to a portion of the wealth created by the nation, but also of individual rights or moral obligations that each person has with all the other individuals that forms the nation.

Basically, this author is against passive citizenship, characterized by the affirmation and assurance of the right to work, which develops into a policy of mere protection and an attempt to guarantee the right to life. This system, however, has generated a tension that led to a crisis between the autonomy thus acquired by the individual and a more general solidarity, since life in the poverty niches, due to the 
excessive number of people to protect, has allowed the vampirism of national society, undermining that same solidarity. An active citizenship is not just about the right to life, but the right to live in society, that is, the right to civil and political involvement which above all implies a retribution from those who benefit. Likewise, it is not just about the right of work, but the right to work, which requires overcoming the contractual interpretation of solidarity. In this contractual concept, social rights belong to the worker at risk, that is, assistance is given to those who cannot work (extended sometimes to the "free riders" who get used to getting the benefits and quit searching for a position in the formal work market), what is guaranteed by the ones who want and can work. Beforehand, solidarity was founded on the contributions made by workers and redistribution was a consequence of workers' aptitude for work. In its current phase, economic globalization has changed it all, for technological changes have deeply altered the working process, and massive unemployment was followed by the growth of the informal market together with the lack of regulations in the relationship capital/labor. As a consequence, the financial crisis of the welfare state rekindled the concern for those who avoid work and developed the "addiction" of dependence, becoming parasites of those who work. So the discussion about the "deserving poor" or the moral aspects of the issue have come up again, this time with more democratic solutions.

The proposition, then, is that the Passive Welfare State should be replaced by the Active Welfare State. The aim would no longer be just to assist the needy but to aid people with different social usefulness, whose capacity could always be put to use. There would also be a radical socialization of goods and responsibilities. The ideology of this new state would bring forward a new concept of solidarity: not private charity or the well-being that come from social rights, nor the mutuality of the 19th century's solidarity. The motto of this ideology - to rebuild the nation - means to promote the solidarity that comes from belonging to the same national community, with a national social security system. In this new sense of the social, since the social issue is national, solidarity means the right and the obligation to integration. In the "Civic Welfare State", as Rosanvallon calls it, civility is built upon a general process of education, inside and outside schools, and becomes an alternative to the often frustrated attempts to amend the unsociable sociability to which Kant refers. In it, ideally, public policies should focus more on the prevention of exclusion than on the reinsertion of the excluded, on the creation of a positive sociability rather than on searching for the cure of the negative, although during current crisis rather the opposite is bound to occur in the policy of reinsertion. This project would be carried out by other actors: not anymore by unions and the redistributing state, but by a series of different associations working with the state - still the main actor for the social - creating a new legitimacy for its intervention.

In the current policies of reinsertion by which one applies a cure to what has notbeen prevented, the French minimum wage program - RMI incorporates some of the considerations about the Active Welfare State and proposes the institutionalization of a social debt, this time with a counterpart: the beneficiary's personal commitment to the national society. In other words, it means that the person would be expected to engage in different activities, either investing in his own schooling, participating in associations that deal with the general interest, or - in case of drug users or petty criminals - trying to readapt to society. The very concept of labor has to be modified, redeeming Keynes propositions from the early 20th century: not the idea of the economically productive labor, which results in the increase of plus value, but the idea of a socially useful labor, which may mean selling orange juice on the streets, helping to clean a poor neighborhood, reforesting state areas in order to reduce unemployment, and even attending the sick, the elderly or the children who are at risk, even if one is not professionally trained to do it. The use of non professionals in solidarity actions is followed by the decentralization of decisions on who should get or go on getting the different kinds of assistance. However, this decentralization is not reduced to the transfer from federal to municipal power; it is instead a net system where the common citizen, workers who represent their profes- 
sional categories and neighborhoods, their associations, religious or other, take part on the same forum of discussions about the criteria and the people to be included in the plan (Affichard, 1995).

Nevertheless, another author - Robert Castel (1995) - due to the above-mentioned theoretical problems, prefers to talk about disaffiliation instead of exclusion, and proposes different policies to solve the issue. The terminological change is important insofar as affiliation refers to a social process, with active people participating in it, and not to a binary logic of classification. Robert Castel also works with the possible and necessary choices within national societies that, even in European countries ethnically and racially homogeneous beforehand, present today a picture of heterogeneity, marked by explicit racism. He stresses the fact that the policies of integration in a national society should not lose sight of situations differentiated by religion, ethnic identity, race and gender, and resume the theme of pluralism and multiculturalism. Even so, like everybody, the author repeats the motto of integration in the national society for those who are the most atomized, the most useless, the most indifferently treated by everyone. That is why he then speaks of "negative individualism", the individualism of those confined in islands by fragmented social tissue, isolated, reduced to nothing, without the socially shared idealism and values; the individualism of those who, through narcissism, have sought the illusion of absolute individual independence and have found the void.

For him, the big challenge of European national societies would be for a part of the population to stir up the existing exile of citizenship and national societies, now predominant in those societies, which would tend to affect everybody. His understanding of exclusion is the closest to the concept of underclass, employed for thinking the situations of housing, morality and work of the members of ethnic minorities in the United States (Jenks, 1992; Katz, 1989; Danzinger and Weinberg, 1986). Since for him the main aspect of exclusion is the end of the salaried condition, which requires a stable employment, a nicely constituted family and a homogeneous religious group or neighborhood, the result is a hazardous and unpredictable life. In it, tomorrow is uncertain due to what temporary work orodd jobs, i.e., the altemation of periods of activity and inactivity, impose today to the able worker. They become, therefore, subjects by default, since they are excluded from all collective protections: family, neighborhood or religious groups, companies, unions, etc. Thus, when analyzing disaffiliation, one should combine national issues to local and to private processes so that one can find antidotes. Here Castel is also closer to the US discussion of justice, which follows the communitarian line, looking for the articulation of this perspective with the universalistic that is conceived in the societal line.

For this reason, Castel argues that the exclusion of the addicted youth is not the same as that of the unemployed, and different public policies are necessary for their integration. He also criticizes welfare policies for their post facto characteristic of remedying a situation instead of preventing it. In a final estimation, he prefers the more forceful employment policies, the only ones that would revert the growing difficulties caused by the end of the "work society". These would be economic policies and would seek to modify the structure of production, with large-scale intervention of the state. Thus his restrictions to the RMI law, that he sees as promoting insertion in an ambiguous way. The "minimal wage for integration" is a national imperative, seen as a mere temporary aid to those who have succumbed to the crisis. However, what was created to be temporary has taken a permanent quality among the unemployed who now live off welfare, transforming the citizen into an addict to idleness.

Thus, Castel is also against neo-philanthropy and agrees that the inserted should contribute with compensations for their insertion, although, contrary to Rosanvallon, he proposes that the political and civil integration with responsibility should be accompanied by real possibilities of a steady job. Following this line of thought, the modern state should redefine its functions and find again its lost legitimacy. According to him, the problem is that the new forms of insertion besides a steady job, the new forms of identity, of solidarity and of social usefulness are more harmful to some people than 
to others. The right to work as opposed to the right of work is not equal for everybody. He even admits that we may be at the end of the wage-based society, or of the job as the main vector of integration, but we have to keep our attention focused on those who remain outside of this long process of the building of a new citizenship, which is far from being completed. Today, the unemployed or the ones assisted by the RMI still consider the job as the biggest expression of dignity and citizenship. What to do with those who are the most damaged by the end of the wage system, that is, the weaker and the dispossessed, the ones that are waiting for the emergence of new forms of identity and of citizenship? Urgent political measures and the restructuring of global economy are still in the horizon of the current debate, which cannot be solved by the magical formula of decentralization in order to integrate the poor.

In present society, social classes, such as were recognized and studied in the 19th century and in the first half of the 20th century, are not the only relevant divisions. Multiple segmentations have created other exclusions and new subjects of right in the following political struggles. In Brazil, for instance, any link between men and women has been institutionalized, buthomosexuals are still excluded from this institutionalization. However, the concept of human rights, which is applied to those categories not granted with civil rights, is less and less invoked as far as the national laws have incorporated their claims. Many of the struggles brought forward as being a human rights issue, especially those referring to institutional violence against the poor, are in fact fights to transform their civil rights into real rights, i.e., not merely formal, for they are already lawful. In Brazil, the poor are not considered foreigners, such as happens with the Arabs and their descendants in France and with African and Antillean blacks in England and France.

We live today, then, between two dangers. The tendency to consider specific rights in detriment of the more general rights, or local identities ignoring the national and even the supranational and international ones, has created the danger of an exaggerated stress on the autonomy of specific communities or localities. This tendency could break up the nation, creating serious problem for the integration of the poor since the social issue, as defined by those authors who thought about it, is basically a national issue. One of the dangers of decentralization of public policies would be the strengthening of local solidarities and identities which would leave out a large number of poor migrants, rejected by the richer municipalities, such as occurs today in several southern states, in the interior of São Paulo and in some municipalities of Minas Gerais. This would represent a reversion to the English policies of the 17th and 18th centuries, characterized by the immobilization of the poor in their municipalities of origin (Himmelfarb, 1984) and of immense inter-municipal differences.

Another danger ensues from the idea of nation as the fatherland that demands sacrifices from its children, including the loss of their specific identities, with which we would end up eliminating completely the diversities for the benefit of a national identity. The question is, therefore, how to rebuild the nation. In so doing, the articulation between recognized levels of sociability and solidarity has to be re-established. Cosmopolitanism does not mean the relinquishing of interpersonal sociability or of reciprocity as the principle of interpersonal ties, but an extension of these ties beyond the small universe of the family, which is the matrix of other primary groups. Therefore, the confines of a neighborhood, or even of the associative trends that are characteristic of modernity, as well as those of trade unions, restricted professional groups, political parties, and enclosed religious groups, have to be surmounted so as to include and integrate the layers of the population, in a more general level, in ampler circuits of solidarity.

One should always bear in mind that the growing option for the concept of exclusion, of French origin, reveals the final purpose of integration, that is, belonging to a higher unity encompassed in the idea of nation. In its turn, this reestablishes the new social issue: it is not just the civil contract between two people or organizations, nor the political contract sponsored and mediated by the state which controls the sovereignty over the territory and the submission of all to the law. In the new social issue we deal with the 
commitment that each one has with the others, that every person belonging to the nation has with everybody else, in circuits of various exchanges (Ricoeur, 1990). At the same time, the universalistic notion of justice based in the idea of equal justice for all becomes relative, opening the way for criteria that are local, situational and diversified, as well as thrived within the different circuits of distribution and exchange, of which the state is not anymore the sole mediator.

The discussion about reciprocity in modern society is, therefore, a theme of utmost actuality, judging by the amount of works published by the M.A.U.S.S. (Mouvement Anti-Utilitariste des Scientistes Sociaux) and others that intend to unravel the market, self-interest and impersonal or bureaucratic rules as the icons of modernity in sociologic thought, inspired by utilitarianism. Instead, they propound to reintroduce interpersonal ties, disdain towards private gains (desintéréssement), communicative rationality and reciprocity within wide circuits as outlets for the predicaments created by neo-liberalism.

\section{Reciprocity in modernity}

One of the most influential currents of Anthropology has characterized the social field as the sphere of reciprocity, of moral ties and interpersonal communication, keeping in sight the ambivalence and contradictions of these terms. As tools for building up of the idea of social order, organization, sociability or positive sociality, these concepts were first adopted, then pretty much criticized and recently recuperated. Today, at the end of the century, numerous social scientists re-start using the terms employed at the beginning of the century because of the fraying of the social tissue, urban violence and social fragmentation that affects all forms of cellular organization, the loss of impetus of social movements, besides the new challenges originated from neo-liberal economic theories still based on the individual and self interest.

It is not by chance that the first theory of reciprocity appeared in the first decades of the 20th century, when liberal market theories prevailed in the pre-Keynesian era, prior to the attempts to fight corrosion in society caused by a market devoid of institutional or moral limits. According to Marcel Mauss' theory, the three moments of reciprocity to give, receive and to return - would form a unity made possible by the character of the gift. The donated good, charged with a vital strength and with the energy that would make retribution obligatory, would create the magic of uniting people and establish social ties among them. The gift would then be the mediator of interpersonal and inter-group links; but it would circulate in the restrict circuit of interpersonal relationships, constituting the community of primary relations.

Mauss, however, did not have a naive conception of donation, for he did stress its negative and ambivalent aspects. The ambivalence of donation would be present in the connotations suggested by its Greek root - dosis - associated to dose, to poison not strong enough to kill if served in small doses, in which case the person is capable of giving it back. The gift, however, would shame those who would getitin doses that they would not be able to reciprocate. In fact, in the several ethnographic examples used to build up his theory, Mauss describes how the donation received without the possibility of retribution can humiliate the receiv$\mathrm{er}^{2}$ becoming even dangerous and phony as in the "Greek gift", a well-known expression in several languages. The donation is also a resource of power much used in rituals of status display, providing the donor with prestige and power, that is, it is not a token made out of pure unselfishness or generosity, although its selfish character is more symbolic than material. Reciprocity is also maintained at the edge of the agon, a force that pushes men into competition, rivalry and revenge when they feel they have suffered grievance or offense (Boilleau, 1995). Donation is at the same time selfishness and unselfishness, generosity and strategic or instrumental calculation, concepts expressed in the symbolic rather than material level, which are maintained in permanent tension, especially in the relations between unequal people. For this reason, Mauss pointed out one of its perversions: the giving of alms in Christian charity, the humiliating philanthropy. We could also add: clientelism in its articulation with the political which has turned personal loyalty into a 
tool for electoral purposes during the First Republic; the neo-clientelism that privatizes public budgets and services today for the same purpose; the loyalty associated with terror that characterizes the personal relations inside the Mafia. All of those possibilities hinder free choice for those who bet on giving, receiving and rendering.

Because they are the basis or the binding element of any sociability, reciprocity and donation in symmetrical and asymmetrical circuits of exchange were not restricted - as Marcel Mauss himself asserted - to the so-called tribal or primitive societies. The specific circuits of modem and contemporary societies in their economic and political consequences as well as in their positive and negative aspects, have been increasingly the object of analysis by countless authors, in different social fields: in healthcare, welfare, blood and organ donation, in the state fiscal policy, in various social movements, but also in the circuits of private revenge and in the modern penal system that has not lost its vindictive character. In the social field there has always been an interweaving between necessity (or interest) and donation, envy and solidarity, despite the overly optimistic assertion of the critics of personal interest as society's binding element. To speak of reciprocity is, therefore, not enough. It is important to know what kind of reciprocity we're talking about, its social context, its communitarian limits, its circuits, who is part of it and based in what criteria.

The current debate about concepts of reciprocity, unselfishness and interest is crucial to bring together the economic, political and social issues that have been so dissociated in the neoliberal nineties, as well as to the understanding of relations in what we call the new social issue. At the same time, the field of debate on justice has been amplified, comprising different branches according to different principles: the principle of legal rights (justice as institution) and the principle of material necessities (social justice). Both, however, are based on the recently resumed discussion about reciprocity and solidarity among men in general (universal and abstract rights and duties) or among real people belonging to specific communities (specific and concrete rights and duties).
This discussion has been impelled by the Anti-Utilitarian Movement of Social Scientists in France, which is trying to retrace the paths of reconstruction of the social tissue, or what Francis Farrugia called the social tie in his book La Crise $d u$ Lien Social. According to the authors of that movement, the social tie or the new forms of reciprocity would serve as the basis for new ways of living in society ("wanting to live together", according to Hannah Arendt's concept). These forms would constitute the new contract of civility that is neither the civil nor the political contract with the state, but rather one made by each member with everybody else within the national community. They would justify the new forms of legitimacy that stress the rational character of the state (according to Habermas and Ricoeur), in which the practice of violence should be limited, controlled and justified. Finally, they would shape new forms of solidarity in which the state is also the promoter of innumerable circuits of reciprocity and solidarity that need definition. We are talking here about reuniting the social and the political or about the re-politicization of social ties, linking them to social rights and citizenship, that is, it is about the overlapping between the Welfare State and the National State.

One of the authors involved in this debate, the Canadian Godbout (1992), tries to build the theoretical space of modern reciprocity that is distinct from the market, the state and the traditional reciprocity which encompasses only domestic communities. Reciprocity is different from the market in so faras it complies the receiver to render the donor - thereby creating a relationship, a tie, a link between partners in an exchange without a limitin time. This social tie allows for a long term protraction of the retribution, depending on how close the partners are. In it, the goods exchanged have above all a symbolic value, marked by the social relations in which they are displayed, consumed or destroyed. In the market, the exchange based on the principle of equivalence or measured by currency (general equivalent) would end the relation as soon as the exchange takes place and the goods have an exchange value that is quantitatively measurable. In the state, the existing principle in the circulation of goods and services is, at least theoretically, that of 
equity and justice in a system that is based upon impersonal and bureaucratic relationships, realized in the concepts of Law, that is, in a perspective of justice that is universalistic and juridical. In domestic communities, where the relationships based on love and friendship prevail, reciprocity is of a restrict or generalized nature, although always within the excluding limits of a community with primary ties, that is, involving people that know each other and have long-time links of affection excluding others. By definition, communities such as families, villages, old neighborhoods, etc., are ruled by countless private and local (non juridical) perspectives of justice. Here the guidelines are those that another author has called "binding value" (Caillé, 1994), which joins and assembles people in lasting relationships.

In a fourth sector, that of modern reciprocity, gifts would be based on generosity towards strangers and would spring from the donor's free and willful action. Itcould be considered impersonal in the sense that the receiver would probably remain unknown, but it does not shun calculations about the possibility of a return in the future through middlemen who act as redistributing agents. Its model was initially considered that of organ and blood donation which, in western countries, are of a totally voluntary nature; today, though, they are not restricted to these goods that, although still of a voluntary nature, need the mediation of and redistribution by the state. Nowadays, othervoluntary and participating associations in which the partners exchange services and other forms of communication that create social relations between them and which require active participation or a responsible commitment in collective objectives, appear as the most representative of the fourth sector. They are, for instance, the alcoholic anonymous, narcotic anonymous and other organizations that should not be likened to non-governmental organizations. In the fourth sector, the state's bureaucratic character of mediator in the redistribution system would not be replaced by another bureaucratic organization that also works as a redistribution node and needs a budget to operate. Likewise, due to the effects of its own presence in the social dynamics, the private and local criteria of justice present in the communitarianism, from which the domestic sector takes its functioning, suffer a variation. Local autonomy, which does not organize the relationships between the various groups or communities, is split so as to form chains of solidarity between strangers whose final aim may be the distribution of some scarce good, based in several justice criteria that imply permanent public discussion about the choice processes of who will be the beneficiaries.

This is why many authors that take part on the debate about the theory of justice have mentioned a "controlled pluralism" (consequence of the different criteria of the community), which would depend upon public discussion of the distribution criteria and of the evaluations submitted by the participants of the solidarity circuits (Ricoeur, 1995; Boltanski, 1990; Rosanvallon, 1995). The effect is also to create different ties, either through donation of goods or through participation in public discussions about evaluation and distribution. In this circuit of reciprocity it would be included not only commercial but also non-commercial goods, such as nationality, welfare, education, administration of justice, that is, different spheres of justice controlled by the state (Walzer, 1995), or still those deriving from the process of justification in the demands for justice and its evaluation, in which the ideas of honor, trust and reputation - immaterial goods not controlled by the state - are proclaimed in the disputes (Thévenot, 1995; Boltanski, 1990). For the same reason, these authors assert that, on the issue of inclusion orparticipation, the allocation of goods is not discussed anymore, being replaced respectively by the (limited) control exerted by the state in each sphere and in the interactions between them, or the social relationship itself. Likewise, Rosanvallon, Walzer, Ricoeur and others suggest the replacement of a strictly juridical view of equality and rights, as well as a purely mechanic concept of goods redistribution, by a remonstrated and publicly discussed practice of the social policies that change the picture of the distribution of political power. Finally, criticism of a merely distributive and utilitarian social justice leads to criticism of the idea of the citizen as a passive subject, a mere 
receiver of what is distributed by social agencies. The distributive theories would not take into account the justice, respect and consideration owed mutually by the citizens in the "democracy of everyday life", that obviously are not goods the government can distribute (Shklar, 1995).

In this debate, where do we find the ambivalence of social life? Where are the individual passions and emotions that are entangled with the rational objectives in action?The symbolic rewards of self-esteem, the quest for notoriety, the disputes that liberate aggressiveness, the ostentation of power and wealth or the search for justification, object of attention from researchers, still show up, although with explicit rules that lead to what Norbert Elias (1993) named "balance of tensions" in extended disputes, though controlled by conventional rules. Elias made a good analysis of this process in what concerned the diffusion of courteous habits by the inhabitants of a country; the adoption of rules applied to the dispute for power that replaced the use of guns by the use of words and of voting in the parliamentary regime, as well as the institutionalization of emotional disputes in sports and other regulated activities by the "pleasure of competing". Sport itself has evolved towards a policy of training and self-control instead of custo mary rules, lenient and hardly applied, that allowed for explosions of emotion and violence in the middle age, often ending with the death of participants. However, during this evolution, in which the role of mediators and of agreed rules have occupied more and more space, the game dynamics continued to presuppose tension and cooperation, local solidarity and interest for the continued struggles in several levels at the same time. In other words, group tensions and cooperation are simultaneously present in the situation of "balance of tensions".

\section{Exclusions and some stirred up circuits of reciprocity in Brazil}

In Brazil, from a rhetoric discourse about freedom, the issues of sociability, reciprocity and communication in the public sphere have been more and more stressed, though still vaguely, as manifestations of citizenship, or even as its core. In fact, individual freedom, in its aspects of negation of the state's control, is fiercely defended by those who would like to see the state and the society submitted to the free market game, in the endless search for profit, and in the inexorable game of human passions, especially in their taste or will for power. How and where should this freedom be limited, controlled or repressed?

The question takes us to the issue of criminality and its rhetorical link with poverty, which sets up a trap to the social scientist. To justify the violent criminality of a small portion of the young men who live in poverty is to deviate the attention from those who should be controlled: those who make fortunes on drug and gun trafficking, on the one hand, and those who misapply the money destined to public policies that would educate this youth for a positive sociability and for the positive rights of participation. It also means a refusal to criticize the ethos of profitat any price that has dominated them and that has created power based on fear and terror in some popular neighborhoods of several Brazilian cities. Gagged by the law of silence, seduced by the appeal of groups of defense or extermination, many poor workers, of various religious and political affiliations, end up by committing themselves to policies that are conservative, authoritarian and in violation of human rights, in their desperate quest to leave a situation that is unbearable to them. We must, therefore, carefully examine the altered patterns of sociability and conflict negotiation in these places where identities seem now to be forged in the logic of war.

For this reason, it seems dangerous to me to present the two sides of the public discussion on criminality in a certain way, dividing not only the general population but also scholars between those who advocate social policies to fight criminality among youngsters (the poor) and those who defend a more efficient policy and justice by means of institutional reforms. The vices and problems of the Brazilian justice system are not few and have been denounced by several authors linked with the defense of human rights, such as Sérgio Adorno (1990), Paulo Sérgio Pinheiro (1991), Antônio Luis Paixão (1988) and myself. Social policies should be 
implemented, not because the poor are a permanent danger to security, not because they are the dangerous classes, but because a democratic and just country cannot exist without such policies. In other words, we should not forget that despite the enormous inequalities existing in this country, few poor youngsters choose criminal careers. Special care or focal policies should be given them, one that considers the social context closer to their actions, whether they have control or not over them.

This takes us to the crux of the matter. It is not a question of opting for the liberal principles that rule that each person makes his own choices independently of social constrictions and habits and aspirations that are external to them. It is the question of analyzing in a more complex way the wider and the local social contexts in order to understand the reasons why a growing number of youngsters (of every social standing) commit crimes, which does not always mean the embracing of a criminal career. Likewise, why some of them end up practicing a kind of military power in the communities where law-enforcing institutions are either absent or are conniving with illegal business or else are too weak; where neighboring organizations have disintegrated or were exhausted by political competition between parties and religious groups (Zaluar, 1995); where paternal and maternal figures are no longer models of behavior and parents are not able to control their children. When this happens, the "balance of tensions" within its solidarity and rivalry networks is shattered. Immature and extremely well armed youngsters get involved in neighboring recreational or political organizations. To ignore this fact is to fail in understanding why some poor youngsters commit crimes and others do not, and why their organizations copy military commands, gangs of autonomous warriors led by a despotic chief.

My reasoning, developed in twenty years of research, places the existence of organized crime related to drug trafficking in the eye of the hurricane. Nowadays, thefts and robberies are internationally linked to the need to pay the drug dealer, if one is a user, or the need to amass enough capital in order to maintain the drug business, in case of the dealer, who uses military power to control his army of collaborators and clients. Well, even if registered crimes are not directly related to drugs, that does not mean that the presence of this new power in capitalist countries is not in operation even at the symbolic level, as a model, a symbolic map.

At world-wide plane, organized crime, which has complex structures and deals with large sums of money, cannot be ignored as the big force that it is, together with the national states, churches, political parties, multinational businesses, etc. In certain countries, like Italy, organized crime has been considered more important than the national state, the Church and the parties. In Brazil, where the justice system is still focused on individual crimes and is not equipped for investigating more important groups and the meanders of organized crime, we have no idea of the impact it has today on institutions and on society. For instance, the interesting remark found in the latest researches (Adorno et al., 1995) about the small incidence of illiteracy among young criminals may be related to "technical" requirements of the organized crime, with account books and elaborate plans that make elementary education an important element in task performing. The current policy of war to drugs and repression to users, especially in countries where the rights of citizenship are feeble, have not freed these countries from the traffic and could not hinder HIV epidemics caused by the use of injected drugs in ports and cities along the criminal route, nor the epidemic of deaths by homicide among young men in the big cities.

Other element of impact, to which I have been alerting since 1986, is not of a lesser magnitude in the social lives of slums and popular neighborhoods of Rio de Janeiro. It is the process that turns an organized gang into a central power in the slums, where they may banish troublesome dwellers, kill rivals, alter the networks of sociability and interfere in the organizations. The next step will be to take over the organizations, impose electoral votes and disseminate terror even inside the workers' homes. The football game played by armed men without a referee is emblematic of this situation. The interference in the choice of the 
samba to be played in the annual parade at Carnival nullifies the conventional rules and justice criteria previously accepted which, while keeping the dispute lively and exciting, did not scare contestants or shut up opponents. The elections at dwellers' associations became more and more contested, resulting in their gradual emptying and, consequently, in a decrease of public participation discussing the allocation of goods and services in the community, and deciding the criteria and justifications to do so. Instead, the local leaders have neared the image of sheriffs like the ones in the slums of Central America, who had been influenced by the culture of cowboys, outlaws and sheriffs of the North American West.

Let's now return to the social issue that is mixed up with "exclusion". In it, besides the "revolution in aspirations" referred to by Tocqueville when describing England after the industrial revolution, and that we know nowadays as "relative deprivation", we cannot disregard the abrupt changes that took place in social organization. No doubt the speed of changes in family organizations, in sexual relations, in the values that considered work as the most important reference for large layers of the population, now replaced by values related to consumerism, especially the consumerism of "style", more expensive and less familiar (Sassen, 1991), promoted what we could call diffused social anomy. Apart from that, it is a fact that deep-rooted participation of organized crime in institutions through corruption, the highly disparate functioning of our penal system and the obsolescence of the penal code have created "islands of impunity" such as the ones conceived by Dahrendorf (1987) to characterize other countries. To talk about this confusion of values and rules of conduct and of institutional weakness at the same time does not mean to ignore poverty.

Nevertheless, in this new scenario, poverty acquires new meanings, new problems and new divisions. The destitution is not only of material goods, even because many of these are more of a symbolic importance - of assertion of a hierarchic position or of an identity through style - than a real need for physical survival. Material and symbolic privation is relative, that is, it exists when comparing with those who have more, but it is also a result of this new kind of consumerism.

Exclusion, which also has to be understood in different levels and processes, is simultaneously deprivation of justice, it is institutional. Studies made in countries with a more egalitarian justice system than the Brazilian one have proved that an English citizen, if he is a man, is less than 21 years old and was raised in an area considered of "delinquency", will have 120 times more chances of being considered a criminal than an Englishwoman older than 21 years old who lives in a middle-class neighborhood (Jones, 1981). This means that the poor would be more at the end of the criminality flow than at its beginning, at least as the promoters of its initial dynamic.

Police corruption has found its alibi in the same dogma of poverty and exclusion that explains everything: the problem would be solely "social" (read "material"). This has assured the impunity of those responsible for illegal and discriminatory activities against youths, especially the poorer ones, those who the public power should defend by treating them in health centers and educating them in schools. Extorted and incriminated by drug use, these youths end up at the hands of dealers and assailants, or are victims of massacres that, when clarified, exhibit their real motives: debt collection or profit division implemented by corrupt policemen. More than extermination groups, extortion groups are the ones that create the environment in which gangs and other even more organized groups fight for turf control. The tendency revealed in cities like São Paulo and Porto Alegre by the end of the eighties (especially the first one, where the rate of homicides has doubled and is still growing) indicates that drug trafficking is also modifying the public security panorama in these cities. The question that arises is if, side by side with the chains of mass communication, quicker and easier each day in the process of culture globalization, the corrupt and violent policemen who use their guns with little institutional control do not exert over the poor youths a fascination for the military power thus operated.

The presence of armed gangs and the wars between them have added an extra hardship for 
the poor men' lives. Even if we accept the fact that not every gang or group of youngsters is linked with criminal activities in Brazil, the growing presence of gangs of drug dealers and assailants is today an irrefutable reality in Brazilian urban centers. In Rio de Janeiro their short-lived immature leadership, that exhibit a high incidence of premature deaths, are important links in the chain of effects that originate the observed high rate of violent deaths among youngsters. It is, therefore, a big mistake to argue that, since the life of crime is notalways the result of personal choice, there is no rupture or distinction among the poor in relation to criminal careers. What really matters is to understand the different processes and their intertwined effects that make these youngsters continuously breach not only the law, but different forms of sociability. Only then can one conceive public policies that may help to prevent that mistrust and hostility result in their mutual destruction.

At the same time, it is a denial of equally important chains of effects the attempt to reduce to social fragmentation the problems and dilemmas of the complex social processes that link the local, the national and the global. According to this determinist theory, poor adolescents are left with no future alternatives besides drugs, delinquency or premature death. Therefore, to demand only more schooling, more professionalization and adequate job opportunities is to simplify the drug issue, in so far as illegal drugs are used by well-paid and prestigious professional groups, like journalists and stock market brokers, or by wealthy university students. The big difference, and here we find another manifestation of this country's inequality, is that poor users do not have the same access to health services to treat them in case of abuse or defend them in case of problems with the law. In short, without a public policy that would modify the current criminating of the use of drugs, without a health policy of risk reduction and prevention of drug use as part of the youngster's education, we will not be able to change the current scenario of violence and injustice existing in the country.

If we do not consider solely his small and temporary material gains, directed by a dangerous rhetoric, we are forced to acknowledge the disas- trous consequences drug trafficking inflicts to this poor youngster that we intend to protect: the war between gangs has already killed and will go on killing thousands of those who have been seduced by the power bestowed from a gun and from belonging to a well-armed gang. It is mainly the young poor men - black, mulatto and white that put their lives in the hands either of violent policemen or of their own friends and accomplices. The political use of this ill-fated fact that adds even more suffering to poor families, may be securing more space in the news, but it is not enabling us to create public policies that would be efficient in lessening the complex problems of this puzzle. We have to deal today simultaneously with a social issue that is also a matter of education and of public health, linked to police and juridicalpenal issues.

Today Brazil is a country that also shows signs of religious intolerance that reverts the effects of historical processes that resulted in the assumed hybridization of its cultures. In the local plane, this new tendency has had unexpected and tragic consequences for the poor families and their neighboring organizations which, from my point of view, has allowed that groups of drug traffickers take over local power. Broken social ties within the family and between neighboring families, have destroyed or inverted the sign in reciprocity circuits: from solidarity to revenge, from the agonistic to the antagonistic, from rivalry expressed in sports and cultural games to deadly rivalry. It is undeniable that there has been a disinvestment in Brazilian traditions, mainly those of Rio de Janeiro, which are now adays considered as inauthentic and manipulative political devices directed to the building of the Brazilian nation. Now, as we well know, every cultural tradition is artificial, fruit of political articulations that serve as substrate or reinforcement for identities in conflict. However, beyond the diacritic signs of difference or of political artificial identities, there remains the social ties, the solidarity networks woven daily within their organizations. The community of meanings is also the community of exchanges based upon the reciprocity principle, outside the logic of the market, which Habermas called "the world of life". 
Encroaching splits within these finely woven social ties is destroying the social fabric and creating social fragmentation, anomie and isolation.

Poor workers that stayed together in neighboring organizations, getting married to form families regardless of race or creed, now watch the shattering of their families and of these organizations, so important in the creation of culture, in achieving moral and political autonomy, in participating in the public debates about justice with all its multifaceted aspects. In my last research at favelas in Rio de Janeiro, I heard depositions from teary-eyed mothers saying that they were born and raised there, that they used to go to samba parties with their whole families, but that now they would like to move from the favela, a place full of conflicts, risks and threats. ${ }^{3}$ A mãe-de-santo (AfroBrazilian female shaman) painfully described how she quit visiting their children converted to the Pentecostal religion because the pastor had forbidden her "charged" and "diabolic" presence in their homes, even at her grandchildren's birthdays. And I saw small children outside adults' attention playing of gang, shouting orders and killing with a toy gun pointed to their subordinates. Even if not the initial effect, leaving the organizations they built up during decades of republican history (Zaluar, 1985; Carvalho, 1987) in the poor neighborhoods of Rio de Janeiro adds one more fuel to this chain of effects, if we consider previous analysis about the importance of reciprocity networks and of conventional rules that allow for the continuous controlled manifestation of emotions in a dispute.

Within the family, estrangements emerge because men belong to different commands (the Red, the Third); because they have different positions in the war trenches that sometimes separate policemen and gangsters; but also because they have been converted to Pentecostal religions that forbid the contact with other religions, presented as devil's manifestations. Furthermore, quick diffusion of youths' new styles that turned young people into consumers of products made specially for them - clothes, musical styles or illegal drugs - has also generated detachments. Family members do notgo together to the samba anymore, and funk balls do not congregate different generations in the same space. The uncle who is a trafficker would like to banish from the favela the nephew that belongs either to another command, to the police or to the Army. The black grandmother, a shaman, cannot visit the homes of Pentecostal children and grandchildren.

The metaphors of war, criticized and yet reinforced by interpretations diffused in the media, are in the process of becoming the logic of war actually followed in the everyday life of this population. It is not by chance that the most sacred and worshiped symbol of the black identity is Zumbi, the black leader who refused to negotiate, to give in, who fought to his death like a brave warrior. This is the model presented to the poor youngster, black or mulatto, in public schools, especially in Rio de Janeiro. It is not by chance that favelas are identified as quilombos and their defenders as quilombolas, despite its internal heterogeneity, despite the fact that today there are more people from the North-East or Minas - without any racial uniformity - than blacks. Likewise, it is not by chance that youths who constitute the cheap work force and scapegoats of organized crime are presented as heroic and rebellious because of the iniquities of social inequality in Brazil or victims of extermination by the police, without any attention to the complex relations between the world of organized crime and the world of legal businesses, including the institutions that should confront it. However, it is exactly by means of these relations and at the expense of gang warfare and police violence that some white middle or upper class adults get rich, profiting from commercial associations with these poor youngsters that end up dead or in prison.

Thus, the city as a stage for rivalry and a meeting place for different groups that live in it is also under a radical transformation. If, at a time, conflicts and competitions between districts, neighborhoods or groups of different affiliations were presented, represented and experienced in public places, gathering people from different parts of the city, of different origins and ages, creating "sociations" (Simmel, 1983), ties, metaphorical and esthetic performances of their dissension, today the "club funk dances" ${ }^{4}$ can seldom 
gather different youth groups without violent and sometimes deadly outcomes. Although meritorious efforts have been made to "civilize" or, as some prefer to put it, "domesticate" these war rituals, its deeper logic should deserve our full attention. The young funk groups develop a war ethos by which they learn how to fight and to be tough, the male attribute most valued and searched for during adolescence. An uncontrolled and uncritical incorporation of youth styles advanced in the process of cultural globalization, not yet appropriately studied among us, as well as the adoption of an extremely repressive policy concerning some of its effects (such as the use of illegal drugs), bolsters this new subjective formation. Without the study of these crucial aspects of the social issue it will be impossible to mount efficient public policies for the construction of a more just and peaceful society.

In a world where ethnic wars inside the nation itself, and molecular wars within the same groups, social classes, ethnic and racial groups and even the same neighborhoods are predominant, it seems that the network of sociability in the private space and of civility in the public have deteriorated. With so many reticular focus of violence, how to define evil, or, if we choose Paul Ricoeur's option, how to combat evil? In fact we do not have any substantive, essential answer of a general nature, despite the efforts of human rights defenders. The concept of evil committed against humankind is historically recent. Humankind would have today absolute values - for instance, against genocide - and the Chart of Human Rights, approved by the United Nations. The evil that touches the humane, such as in genocide or in attempts against human rights is a modern concept, only two hundred years old in the Enlightened western tradition (Ricoeur, 1986).

The problem is that in molecular violence, even if it is increasingly less private, these general terms of human rights do not apply easily. On the contrary, they create a huge dissension among those who are the targets of violence and feel fear, and those who become fascinated with the power thus acquired. It has become necessary, therefore, to analyze each case in its context, each context in its multiple aspects, each aspect in its specific process. Thus we would not have two opposing fields of confrontation, but one struggle diversified in several fronts. Avoiding the trap of relativism and yet relativizing, we have to analyze the consequences of violent acts for the person or group that practice them, as well as the effects of their acts on third parties, mere passers-by, spectators, innocent victims, part of the fight for survival imposed by the dispute for urban territories, part of the rivalries around which proud men move in search for money, power and prestige.

The same people who enunciate the globalization of the economy insistin repeating a formula used to criticize the security policy of the Old Republic - the social issue is not a police issue denying the phenomenon of crime globalization. However, criminality in Brazil had then different characteristics from those found today. The country's prisons were then filled by vagrants and troublemakers. Nowadays prisons are filled with poor criminals involved in drug trafficking, robbing and stealing in order to pay their debts with drug dealers, amassing capital through kidnapping in order to establish themselves in the business, or starting their careers with a sentence of prison because of a plain marijuana cigarette.

There is a need today of understanding the recent wave of violence not only as a geological effect in the cultural layers of the usual violence in Brazil, butalso within the scenery of internationally organized crime, itself part of the globalization process, with economical, political and cultural characteristics that are sui generis, in the scenario of a capitalism with an unbridled search for profit at any price. One cannot deny, in face of the evidence, the urge to extend the analysis outside national borders, in the study of criminal society, that is, of those who opt to live not always as outlaws, but in a peculiar mixture of legal and illegal businesses. To simplify the issue, the image of the slum kid who, with an AR15 or an UZI machine gun in his hand, which he considers as symbols of his virility and source of a great local power, wearing a cap inspired by the black movement in the United States, listening to funk music, sniffing cocaine produced in Colombia, yearning 
for the latest model of Nike sneakers and a brand new car, cannot be explained only by the minimum wage level or by growing unemployment in Brazil, neither by the customary violence of Brazilian Northeastern inland. The questions concerning who brought him these tools of pleasure and power and how these values were established and are still being reinforced in him, compelling him to go on searching in such a way for pleasure and power, are obviously questions that do not derive from the local minimum wage. Therefore, buying guns easily in the United States is part of this social context, as well as the drug war policy which proved to be inefficient and expensive for reducing the use of illegal drugs but extremely effective in raising the level of violence among blacks. It is the high level of homicides among blacks that lead conservative observers to assert that there is not a crime problem in the United States, but rather a black crime problem, in the peculiar segregated view of the US society or, worse still, that conservative politicians should wash their hands with their minds at rest, because the responsibility for the killings belong exclusively to the black people.

Such assertions, as become clear for the attentive reader, do not imply a standing against the raise of the minimum wage or against income distribution in a country that presents one of the highest rate of social inequality in the world. They are instead a warning to the fact that the raising of the minimum wage alone or the implementation of public policies that do not contemplate the specificity of the new criminality will not be sufficient or effective. The strategy of stressing the high profits of what slum dwellers call "easy money" is to decree the failure of any social policy, for it is very rare to find jobs, even middle-class ones, that offer levels of income such as those obtained in illegal drugs traffic. At the same time, it is necessary to develop theoretical tools to understand these killings, this violent antagonism that ignores rules of sociability, of mutual respect, of the other's recognition, and that classifies any minimal difference in home locality, group, gang - or of any celebrated urban tribes that redefined social identities in terms of territoriality - as a sign of a deadly foe, of the "German" who should be killed, in an obvious though incomplete imitation of the gangs existing in the United States since the beginning of the century (Zaluar, 1997a and 1997b).

Such a great task, involving so many and complex processes, cannot be the exclusive object of one instance or organization (whether governmental or not). Moreover, these problems will not be solved by the repressive functioning of the justice system which punishes the small criminal, less important in the chain of the involved and less responsible, so to speak, for departing the flow of criminal activities, especially those connected with drug trafficking (Zaluar, 1997c). Likewise, they will notbe solved only by policies of job offers or salary raises, including for civil servants, among them the police, the most active category in today's union movements.

Job alternatives for the young are important, but above all it is fundamental to restore local networks of positive reciprocity, to reinforce the weakened solidarity between generations, within and outside classes. As far as public policies are concerned, one should open political space for the recognition and establishment of partnerships with all forms of associations that promote reciprocities and solidarities, especially in the fourth sector. One should also be aware of and to respond to the insidious tendencies of globalization, via the media and the cultural industry, especially those that have altered the forms of sociability and solidarity above-mentioned, especially those dealing with the youths that belong to the poorer layers of society. That is why an intense work with the latter is needed, to regain their hearts and minds, with an appreciation for that which was created in the country by political initiative and cultural creativity of the layers of society called the common people, the subordinates, the workers or the dominated. Once solidarity networks are re-established and conditions are given so that sociability can maintain local societies alive and social games mobilized, it is possible to sustain that the election of committees and commissions, which have multiplied throughout the country, be made locally (and not nominated by the government), giving them more legitimacy. Given the precarious functioning of this democracy that intends to go beyond the 
limits of electoral or representative democracy, the problems faced by these committees have undermined attempts to call the new democratic procedures as participative, such as the participative budget of city halls, the committees of the Solidary Community, etc. Last but not least, democratic policies of public safety will bring back the social and cultural effervescence that workers (from the formal and informal sectors of economy) have lost with the growing violence between their neighbors and the police, especially the Military Police. This has already happened in several slums and public housings of Rio de Janeiro during the brief police work performed by the Civil Police based in new rules of respect for the dwellers. On this occasion, streets and alleys were again filled with children playing ball, adults playing games on tables set on the street (Alvito, 1997) and talking only for the pleasure of chattering, besides celebrations and parties that always offer opportunities to activate and accelerate the various circuits of reciprocity. Thus they would rebuild the eternally sought after union, the guarantee against ato mization, negative individualism and social fragmentation that so worry social scientists who study post-traditional and post-industrial societies.

\section{NOTES}

1 The debate between universalists and communitarians has stirred much more the academic world in North America, but it will not be dealt with here. The book Liberals and Communitarians (Mulhall and Swift, 1992) presents part of this debate that centered on the work of J. Rawls. The authors mentioned here broke up the postulations of non-social individualism and even the idea of contracts between free and equal individuals, basis of civil contracts, which have been criticized by American universalists.

2 In Brazilian folklore, the expression "it either humiliates the man or addicts the citizen" when referred to the giving of alms is the most perfect translation of what Mauss meant about non-returnable gifts.

3 In some shantytowns of Rio de Janeiro, it is calculated that $30 \%$ of its original population has already left the premises due to its violence (O Globo, May 23, 1996).

4 In Rio de Janeiro there are two types of funk parties: those of "the communities", attended solely by youngsters who live in the neighborhood or shanty town, where there are no conflicts, and those of "the clubs", in which young people from different areas gather with the purpose to confront each other ritually inside the parties and actually outside them after the dance finishes (Cecchetto, 1997).

\section{REFERENCES}

ADORNO, Sérgio. (1990), Violência Urbana, Justiça Criminal e Organização Social do Crime. São Paulo, Center for the Study of Violence, Universidade de São Paulo, mimeo.

ADORNO, S., BIDERMAN, F., FEIGUIN, D. and LIMA, R.S. (1995), OJovem e a Criminalidade Urbana de São Paulo. São Paulo, SEADE/NEV-USP.

AFFICHARD, Joëlle. (1995), “Du Débat sur les Inegalités au Pluralisme Contrôlé", in J. Affichard and J.B. Foucauld (eds.), Pluralisme et Equité, Paris, Commissariat Général du Plan, Éditions Esprit.

ALVITO, Marcos. "Notas sobre um Bicho de Sete Cabeças", in A. Zaluar and M. Alvito, Cem Anos de Favela, forthcoming.

BOILLEAU, Jean-Luc. (1995), Conflit et Lien Social: La Rivalité contre la Domination. Paris, Edition La Décourverte/M.A.U.S.S.

BOLTANSKI, Luc. (1990), L'Amour et la Justice Comme Compétences; Trois Essais de Sociologie de l'Action. Paris, Éditions Métailié.

CAILÉ, Alain. (1994), Don, Intérêt et Désintéressement; Bourdieu, Mauss, Platon et Quelques Autres. Paris, Éditions La Découverte/ M.A.U.S.S.

CARVALHO, José Murilo de. (1987), Os Bestializados; o Rio de Janeiro e a República que Não Foi. São Paulo, Companhia das Letras.

CASTEL, Robert. (1995), Les Métamorphoses de la Question Sociale; Une Chronique du Salariat. Paris, Librairie A. Fayard.

CASTELS, Manuel and MOLENKOPF, John (ed.). (1992), Dual City: Restructuring New York. New York, Russel Sage Foundation.

CECCHETTO, Fátima. (1997), "Galeras Funk Cariocas: Entre o Lúdico e o Violento", in H. Vianna, Galeras Cariocas, Rio de Janeiro, Editora da UFR.

DAHRENDORF, Ralph. (1987), A Lei e a Ordem. Brasília, Tancredo Neves Institute. 
DANZINGER, Sheldom and WEINBERB, Daniel (eds.). (1986), Fighting Poverty. Boston, Harvard University Press.

ELIAS, Norbert and DUNNING, Eric. (1993), Quest for Excitement, Sport and Leisure in the Civilizing Process. Paperback first edition, Oxford, Blackwell.

FARRUGIA, Francis. (1993), La Crise du Lien Social. Paris, Éditions L'Harmattan, Collection Logiques Sociales.

GODBOUT, Jacques T. (1992), L'Esprit du Don . Paris, Éditions la Découverte.

HABERMAS, Jürgen. (1991), Pensamento PósMetafísico. Rio de Janeiro, Tempo Brasileiro.

HIMMELFARB, Gertrud. (1984), The Idea of Poverty. London, Faber and Faber.

JENKS, Christopher. (1992), "The Ghetto" and "The Underclass", in C. Jenks, Rethinking Social Policy, Boston, Harvard University Press.

JONES, Howard. (1981), "Punishment or Correction?”, in H. Jones, Society against Crime, Middlesex/ New York, Penguin Books.

KATZ, Michael. (1989), "Interpretations of Poverty in Post-Industrial Cities" and "The Underclass?", in M. Katz, The Undeserving Poor, New York, Pantheon Books.

PAIXÃO, Antonio L. (1988), "Crime, Controle Social e Consolidação da Cidadania”, in F.W. Reis and G. O’Donnell (eds.), A Democracia no Brasil: Dilemas e Perspectivas, São Paulo, Vértice.

PINHEIRO, Paulo S. et al. (1991), "Violência Fatal: Conflitos Policiais em São Paulo (81-89)". Revista da USP, 95.

RICOEUR, Paul. (1986), O Mal. Campinas, Papirus.

. (1990), Soi-Même comme un Autre. Paris, Le Seuil.

(1995), "La Place du Politique Dans une Conception Pluraliste des Principes du Juste", in J. Affichard and J.B. Foucauld (eds.), Pluralisme et Equité, Paris, Commissariat Général du Plan, Éditions Esprit.

ROSANVALLON, Pierre. (1995), La Nouvelle Question Sociale. Paris, Éditions du Seuil.

SASSEN, Saskia. (1991), The Global City: New York, London, Tokyo. Princeton, Princeton University Press.
SHKLAR, Judith. (1995), "Justice et Citoyenneté”, in J. Affichard and J.B. Foucauld (eds.), Pluralisme et Equité, Paris, Commissariat Général du Plan, Éditions Esprit.

SIMMEL, Georg. (1983), "A Natureza Sociológica do Conflito"; "A Competição" and "Sociabilidade, um Exemplo de Sociologia Pura ou Formal", in Simmel, São Paulo, Ática.

TAMBIAH, Stanley J. (1997), "Conflito Etnonacionalista e Violência Coletiva no Sul da Ásia”. Revista Brasileira de Ciências Sociais, 12, 34: 5-24.

THÉVENOT, Laurent. (1995), “L'Action Publique contre l'Exclusion Dans des Approches Pluralistes du Juste", in J. Affichard and J.B. Foucauld (eds.), Pluralisme et Equité, Paris, Commissariat Général du Plan, Editions Esprit.

WALZER, Michael. (1995), "Exclusion, Injustice et État Démocratique", in J. Affichard and J.B. Foucauld (eds.), Pluralisme et Equité, Paris, Commissariat Général du Plan, Éditions Esprit.

ZALUAR, Alba. (1985), A Máquina e a Revolta. São Paulo, Brasiliense.

(1995), “O Medo e os Movimentos Sociais". Proposta, ano 23, 66: 24-32.

(1997a), "Gangs, Galeras e Quadrilhas: Globalização, Juventude e Violência”, in H. Vianna, Galeras Cariocas, Rio de Janeiro, Editora da UFRJ.

. (1997b), “As Imagens da e na Cidade: A Superação da Obscuridade". Cadernos de Antropologia e Imagem, 3,2.

(1997c), Justiça, Violência e Dinheiro Fácil. Paper presented at the Institut des Hautes Études sur la Justice, Paris, March. 